\title{
Effects of Catalyst Crystal Structure on the Oxidation of Propene to Acrolein
}

\author{
Zheng Zhai, Maïté Wütschert, Rachel Licht and Alexis T. Bell* \\ Department of Chemical and Biomolecular Engineering \\ The University of California Berkeley \\ Berkeley, CA 94720-1462 USA
}

\author{
Revised Version \\ Catalysis Today
}

June 5, 2015

*To whom correspondence should be addressed: bell@ cchem.berkeley.edu

0

(C) 2015. This manuscript version is made available under the Elsevier user license http://www.elsevier.com/open-access/userlicense/1.0/ 


\begin{abstract}
Bismuth molybdate is known to be active for the oxidation of propene to acrolein and its activity can be altered by substitution of other elements (e.g., Fe, V, W) into the scheelite phase of $\alpha-\mathrm{Bi}_{2} \mathrm{Mo}_{3} \mathrm{O}_{12}$. This work has further revealed that the apparent activation energy for acrolein formation correlates with the band gap of the catalyst measured at reaction temperature. It is, therefore, of interest to establish to how the crystal structure of the catalyst affects the activation energy. We report here an investigation of propene oxidation conducted over $\mathrm{Bi}, \mathrm{Mo}, \mathrm{V}$ oxides having the aurivillius structure with the composition $\mathrm{Bi}_{4} \mathrm{~V}_{2-\mathrm{x}} \mathrm{Mo}_{\mathrm{x}} \mathrm{O}_{11+\mathrm{x} / 2}(\mathrm{x}=0-1)$ and compare them to oxides having the scheelite structure with the composition $\mathrm{Bi}_{2-\mathrm{x} / 3} \mathrm{Mo}_{\mathrm{x}} \mathrm{V}_{1-\mathrm{x}} \mathrm{O}_{12}(\mathrm{x}=0-1)$. The aurivillius-phase catalysts again show a correlation between the apparent activation energy and the band gap of the oxide, and the only difference being that for a given band gap, the apparent activation energy for the aurivillius-phase catalysts is $1.5 \mathrm{kcal} / \mathrm{mol}$ higher than that for the scheelite-phase catalysts. This difference is attributed to the lower heat of propene adsorption on the aurivillius-phase catalysts. A further finding is that for catalysts with band gaps greater than $\sim 2.1 \mathrm{eV}$, the acrolein selectivity is $\sim 75 \%$ for the conditions used and independent of the propene conversion. When the band gap falls below $\sim 2.1 \mathrm{eV}$, the intrinsic selectivity to acrolein decreases rapidly and then decreases further with increasing propene conversion. This pattern shows that when the activity of oxygen atoms at the catalyst surface becomes very high, two processes become more rapid - the oxidation of the intermediate from which acrolein is formed and the sequential combustion of acrolein to $\mathrm{CO}_{2}$.
\end{abstract}

Keywords: Aurivilius; selective oxidation; bismuth molybdate 


\section{Introduction}

The oxidation of propene to acrolein has been widely studied because of the importance of acrolein as a monomer for acrylic polymers [1,2]. The principle catalysts used to promote this reaction are bismuth molybdates in which a part of the molybdenum is substituted by one or more other metals in order to enhance the catalyst activity and selectivity [3-10]. A number of groups have investigated the mechanism of propene oxidation on $\alpha-\mathrm{Bi}_{2} \mathrm{Mo}_{3} \mathrm{O}_{12}$ with the aim of understanding the elementary processes leading to acrolein and the influence of added elements on these processes [11-16]. These efforts have led to the following findings. On a fully oxidized catalyst, propene oxidation occurs via a Mars van Krevelen mechanism in which propene adsorbs reversibly and then reacts with an oxygen atom of the catalyst. This rate-limiting step leads to cleavage of one of the $\mathrm{C}-\mathrm{H}$ bonds of the methyl group of the adsorbed propene and results in the formation of an adsorbed $\mathrm{OH}$ group and a loosely adsorbed allyl radical that is rapidly stabilized as an adsorbed vinylalkoxide. Loss of an $\mathrm{H}$ atom from the later species leads to the formation of acrolein. Consistent with this mechanism and with the observed kinetics, the rate of acrolein formation is first order in the partial pressure of propene and zero order in the partial pressure of oxygen.

Several investigations have shown that the apparent activation energy for propene oxidation to acrolein can be reduced by the replacement of Mo by Fe or V for catalysts maintaining a scheelite structure over fully oxidized catalyst [17-21]. We have reported in previous sections that the activation barrier for the rate-limiting step is well described by the band-gap of such catalysts, the activation energy decreasing with the band gap [22]. What is not known, though, is how the correlation might be affected by the crystal structure of the catalyst. Therefore, the present study was undertaken in order to extend 
the exploration of the relationship between catalyst composition/structure and catalyst activity/selectivity to a different crystal structure.

The oxide phase chosen for study is the aurivillius structure [23]. This phase has the general stoichiometry of $\mathrm{Bi}_{2} \mathrm{~A}_{n-1} \mathrm{~B}_{n} \mathrm{O}_{3 n+3}$ and consists of $n$ perovskite-like layers $\left(\mathrm{A}_{n-}\right.$ ${ }_{1} \mathrm{~B}_{\mathrm{n}} \mathrm{O}_{3 \mathrm{n}+1}$ sandwiched between bismuth-oxygen sheets $\left(\mathrm{Bi}_{2} \mathrm{O}_{2}\right)^{2+}[23]$. The simplest crystal structure has $\mathrm{n}=1$ and corresponds to $\mathrm{Bi}_{2} \mathrm{MoO}_{6}$ (the gamma phase of the bismuth molybdate) or $\mathrm{Bi}_{2} \mathrm{WO}_{6}$. $\mathrm{Bi}_{4} \mathrm{~V}_{2} \mathrm{O}_{11}$ also corresponds to the first member of the family of aurivilius compounds but is oxygen deficient and can be expressed as $\left(\mathrm{Bi}_{2} \mathrm{O}_{2}\right)\left(\mathrm{VO}_{3.5} \square_{0.5}\right)$ [24]. Figure 1 shows the structure of $\mathrm{Bi}_{4} \mathrm{~V}_{2} \mathrm{O}_{11}$ and illustrates the $\left(\mathrm{Bi}_{2} \mathrm{O}_{2}\right)^{2+}$ layers alternating vanadium oxygen tetrahedra and oxygen-deficient octahedral [24,25]. Each bismuth atom is coordinated to four oxygen atoms of the $\left(\mathrm{Bi}_{2} \mathrm{O}_{2}\right)^{2+}$ layer and to two oxygen atoms (top or bottom oxygen of the octahedral) that are coordinated to the vanadium, and each vanadium is connected to eight oxygen. The work presented here reveals the similarities and differences between the mechanism and kinetics of propene oxidation to acrolein over oxides having an aurivillius structure with the stoichiometry $\mathrm{Bi}_{4} \mathrm{~V}_{2-\mathrm{x}} \mathrm{Mo}_{\mathrm{x}} \mathrm{O}_{11+\mathrm{x} / 2} \quad(\mathrm{x}=0-1)$ and oxides having a scheelite structure with the stoichiometry $\mathrm{Bi}_{2-\mathrm{x} / 3} \mathrm{Mo}_{\mathrm{x}} \mathrm{V}_{1-\mathrm{x}} \mathrm{O}_{4}(\mathrm{x}=0-1)$.

\section{Methods}

\subsection{Catalyst Preparation}

Molybdenum substituted bismuth vanadate catalysts $\left(\mathrm{Bi}_{4} \mathrm{~V}_{2-\mathrm{x}} \mathrm{Mo}_{\mathrm{x}} \mathrm{O}_{11+\mathrm{x} / 2}\right)$ were prepared by the complexation method, as described in more detail elsewhere [17]. Bismuth (III) nitrate pentahydrate $\left(\mathrm{Bi}\left(\mathrm{NO}_{3}\right)_{3} \cdot 5 \mathrm{H}_{2} \mathrm{O}\right)(99.98 \%$ Sigma-Aldrich), ammonium metavanadate $\left(\mathrm{NH}_{4} \mathrm{VO}_{3}\right)$ (99\% Sigma-Aldrich) and ammonium molybdate tetrahydrate 
$\left(\left(\mathrm{NH}_{4}\right)_{6} \mathrm{Mo}_{7} \mathrm{O}_{24} \cdot 5 \mathrm{H}_{2} \mathrm{O}\right)(99.98 \%$ Sigma-Aldrich) are used as precursors. These metal precursors were mixed to achieve atomic ratios of $\mathrm{Bi}: \mathrm{V}: \mathrm{Mo}=4:(2-\mathrm{x}): \mathrm{x}$ in order to produce materials with the stoichiometry $\mathrm{Bi}_{4} \mathrm{~V}_{2-\mathrm{x}} \mathrm{Mo}_{\mathrm{x}} \mathrm{O}_{11+\mathrm{x} / 2}$. The metal precursors were added $50 \mathrm{~mL}$ of water together with citric acid (1:1 molar ratio with metal precursors). The resulting solution was heated at $353 \mathrm{~K}$ for about $24 \mathrm{~h}$ in air to form a gel. The gel was then dried at $393 \mathrm{~K}$ and calcined in flowing air at $1023 \mathrm{~K}$ for $12 \mathrm{~h}$. The material was then slowly cooled in air at $30 \mathrm{~K} / \mathrm{h}$ to $573 \mathrm{~K}$ and then at $60 \mathrm{~K} / \mathrm{h}$ to room temperature.

\subsection{Catalyst Characterization}

X-ray diffraction patterns were obtained with a Bruker-AXS D8 Discover GADDS diffractometer using $\mathrm{Cu} \mathrm{K} \alpha$ radiation. Data were collected in the range of $10^{\circ}<$ $2 \theta<80^{\circ}$ every $0.02^{\circ}$.

Diffuse reflectance UV-VIS-NIR spectra were acquired using a Fischer Scientific EVO 300 spectrometer equipped with a Praying Mantis reflectance chamber and an in situ high pressure cell (Harrick Scientific, Inc), fitted with quartz windows. Spectra were referenced to the diffuse reflectance spectrum of a Teflon reference tile. The procedure used to extract band gap energies from absorption edge data is given in the Supporting Information.

\subsection{Catalyst Activity and Selectivity}

Measurements of reaction rates and product distributions were performed using a packed bed quartz tube reactor $(10 \mathrm{~mm}$ in diameter) loaded with $100-800 \mathrm{mg}$ of catalyst. The catalyst was preheated to the reaction temperature in air over night prior to starting a reaction. The operating temperature is between $623 \mathrm{~K}$ and $713 \mathrm{~K}$ and assures that no bulk 
phase changes occurred in the catalyst. All experiments were carried out at atmospheric pressure with 3.3-16.7\% propene (99.9\%, Praxair) and 3.3-16.7\% oxygen (supplied from $20 \%$ oxygen in helium, Praxair), balanced as needed with additional helium $(99.995 \%$, Praxair). Organic products were analyzed using a gas chromatograph (GC) equipped with a 30 m HP-PLOT Q column and a flame ionization detector (FID). An Alltech Hayesep DB packed column and a thermal conductivity detector (TCD) were used to analyze for oxygen, $\mathrm{CO}$ and $\mathrm{CO}_{2}$. Data were collected at steady-state. Conversion was calculated on the basis of products formed and product selectivity was defined as the moles of propene converted to the product over the sum of the moles of olefins converted to all products, based on a carbon balance. All selectivities reported in this study are intrinsic selectivity, extrapolated when the conversion is very low $(<1 \%)$.

\section{Results}

\subsection{Catalyst Characterization}

Powder X-ray diffraction patterns of $\mathrm{Bi}_{4} \mathrm{~V}_{2-\mathrm{x}} \mathrm{Mo}_{\mathrm{x}} \mathrm{O}_{11+\mathrm{x} / 2}$ for $\mathrm{x}=0,0.05,0.1$, and 1.0 are shown in Figure 2. Comparison of these patterns with those in the literature shows that each material is a pure phase $[26,27] . \mathrm{Bi}_{4} \mathrm{~V}_{2} \mathrm{O}_{11}$ is stable in the $\alpha$-phase polymorph for temperatures of below $723 \mathrm{~K}$, and therefore the diffraction pattern for this material is assigned to $\alpha-\mathrm{Bi}_{4} \mathrm{~V}_{2} \mathrm{O}_{11}$. For $\mathrm{Bi}_{4} \mathrm{~V}_{2-\mathrm{x}} \mathrm{Mo}_{\mathrm{x}} \mathrm{O}_{11+\mathrm{x} / 2}$ where $\mathrm{x}=0.5$ and 0.1 , the material is taken to be in the $\beta$-phase based on previous studies showing this phase to be stable for $0.05<\mathrm{x}<0.225[25,28]$.

The UV-Vis diffuse reflectance spectra of $\mathrm{Bi}_{4} \mathrm{~V}_{2-\mathrm{x}} \mathrm{Mo}_{\mathrm{x}} \mathrm{O}_{11+\mathrm{x} / 2}$ are shown in Figure 3. $\mathrm{Bi}_{4} \mathrm{~V}_{2} \mathrm{O}_{11}$ has the lowest absorption edge, and $\gamma-\mathrm{Bi}_{2} \mathrm{MoO}_{6}$ has the highest absorption edge. The absorption edge for $\mathrm{Bi}_{4} \mathrm{~V}_{1.9} \mathrm{Mo}_{0.1} \mathrm{O}_{11.05}(\mathrm{x}=0.1)$ is lower relative to that for $\gamma$ - 
$\mathrm{Bi}_{2} \mathrm{MoO}_{6}$, and exhibits only a single absorption edges. This result indicates that vanadate and molybdate ions are not electronically independent, and there is presumably coupling between Mo and V electronic states. Band gaps were determined from the UV-Vis absorption data for the fully oxidized catalyst at $673 \mathrm{~K}$ can be calculated using the method described in the Supporting Information, and the results are listed in Table 1.

\subsection{Measurements of reaction rates and product selectivities}

The main products of propene oxidation over $\mathrm{Bi}_{4} \mathrm{~V}_{2-\mathrm{x}} \mathrm{Mo}_{\mathrm{x}} \mathrm{O}_{11+\times / 2}$ are acrolein, $\mathrm{CO}_{2}$, $\mathrm{CO}$, acetic acid, and acetaldehyde. The rates of propene consumption at $673 \mathrm{~K}$ over $\mathrm{Bi}_{4} \mathrm{~V}_{2} \mathrm{O}_{11}, \mathrm{Bi}_{4} \mathrm{~V}_{1.9} \mathrm{Mo}_{0.1} \mathrm{O}_{11.05}$, and $\gamma-\mathrm{Bi}_{2} \mathrm{MoO}_{6}$ are presented in Table 2 together with the product selectivities. In all cases, the data have been extrapolated to a propene conversion of zero. The overall activity for propene oxidation increases in the order $\mathrm{Bi}_{4} \mathrm{~V}_{2} \mathrm{O}_{11}<$ $\mathrm{Bi}_{4} \mathrm{~V}_{1.9} \mathrm{Mo}_{0.1} \mathrm{O}_{11.05}<\gamma-\mathrm{Bi}_{2} \mathrm{MoO}_{6}$, whereas the selectivity to acrolein increases in the reverse order and the selectivities to $\mathrm{CO}_{2}$ and $\mathrm{CO}$ increase in the same order as the overall activity.

The effect of propene conversion on product selectivity was investigated by varying the space velocity of the feed. Figure 4 shows that while the product selectivity is almost constant with propene conversion for $\gamma-\mathrm{Bi}_{2} \mathrm{MoO}_{6}$, a very different pattern is observed for $\mathrm{Bi}_{4} \mathrm{~V}_{2} \mathrm{O}_{11}$ and $\mathrm{Bi}_{4} \mathrm{~V}_{1.9} \mathrm{Mo}_{0.1} \mathrm{O}_{11.05}$. In both cases, the selectivity to acrolein decreases and the selectivities to $\mathrm{CO}_{2}$ and $\mathrm{CO}$ increase with increasing propene conversion, indicating that acrolein undergoes secondary combustion to $\mathrm{CO}_{\mathrm{x}}$. Notably, though, the selectivities to acetaldehyde and acetic acid do not exhibit strong changes with the feed space velocity.

The dependence of the rate of acrolein formation on the partial pressures of propene and oxygen can be expressed in the form of a power-law model given by Eqn. 1 . 


$$
\text { rate }_{\text {acrolein }}=k_{\text {app }} P_{C_{3} H_{6}}^{m} P_{O_{2}}^{n}
$$

Where $k_{\text {app }}$ is the apparent rate coefficient, $P_{i}$ is the partial pressure of reactant $i$, and $m$ and $n$ are the orders in propene and oxygen, respectively. Values for $m$ and $n$ at $673 \mathrm{~K}$ are given in Table 1 for propene oxidation to acrolein over $\mathrm{Bi}_{4} \mathrm{~V}_{2-\mathrm{x}} \mathrm{Mo}_{\mathrm{x}} \mathrm{O}_{11+\mathrm{x} / 2}(\mathrm{x}=0,0.1$, and 1.0). The data show that the rate of propene oxidation to acrolein is nearly first-order with respect to the partial pressure of $\mathrm{C}_{3} \mathrm{H}_{6}$ and nearly zero-order with respect to the partial pressures of $\mathrm{O}_{2}$.

Reaction orders for $\mathrm{C}_{3} \mathrm{H}_{6}$ and $\mathrm{O}_{2}$ were also measured for the main byproduct produced over $\gamma-\mathrm{Bi}_{2} \mathrm{MoO}_{6}, \mathrm{CO}_{2}$ and $\mathrm{CO}$. The rates of $\mathrm{CO}_{2}$ and $\mathrm{CO}$ production are both nearly first order in $\mathrm{C}_{3} \mathrm{H}_{6}$. The partial pressure dependence on $\mathrm{O}_{2}$ is 0.4 for $\mathrm{CO}_{2}$ and 0.9 for $\mathrm{CO}$, which is consistent with our previous results from $\alpha-\mathrm{Bi}_{2} \mathrm{Mo}_{3} \mathrm{O}_{12}$ [17]. This suggests that the oxygen atoms in $\mathrm{CO}_{2}$ come from both gas-phase oxygen and lattice oxygen, and mainly from the gas phase for the production of $\mathrm{CO}$. This is a further indication of the same mechanism for $\mathrm{CO}$ and $\mathrm{CO}_{2}$ production compared with $\alpha$ $\mathrm{Bi}_{2} \mathrm{Mo}_{3} \mathrm{O}_{12}$.

Arrhenius plots for propene oxidation to acrolein over $\mathrm{Bi}_{4} \mathrm{~V}_{2-\mathrm{x}} \mathrm{Mo}_{\mathrm{x}} \mathrm{O}_{11+\mathrm{x} / 2}$ are shown in Figure 5 for temperatures in the range of $623 \mathrm{~K}-713 \mathrm{~K}$. Values of the apparent activation energy are listed in Table 1. The apparent activation energy for $\mathrm{Bi}_{4} \mathrm{~V}_{1.9} \mathrm{Mo}_{0.1} \mathrm{O}_{11.05}(\mathrm{x}=0.1)$ is similar but higher to that for $\mathrm{Bi}_{4} \mathrm{~V}_{2} \mathrm{O}_{11}$. The apparent activation energy for acrolein production on $\gamma-\mathrm{Bi}_{2} \mathrm{MoO}_{6}$ is $18.8 \mathrm{kcal} / \mathrm{mol}$, but smaller compared than that for $\alpha-\mathrm{Bi}_{2} \mathrm{Mo}_{3} \mathrm{O}_{12} 19.9 \mathrm{kcal} / \mathrm{mol}$ [17]. The values of these activation energies are comparable to those reported by Krenzke et al. for $\gamma-\mathrm{Bi}_{2} \mathrm{MoO}_{6}$ and $\alpha$ $\mathrm{Bi}_{2} \mathrm{Mo}_{3} \mathrm{O}_{12} 15 \mathrm{kcal} / \mathrm{mol}$ and $18 \mathrm{kcal} / \mathrm{mol}$ for temperatures above $693 \mathrm{~K}$ [29]. 


\section{Discussion}

4.1 Mechanism of propene oxidation on $\gamma-\mathrm{Bi}_{2} \mathrm{MoO}_{6}, \mathrm{Bi}_{4} \mathrm{~V}_{2} \mathrm{O}_{11}$ and on $\mathrm{Bi}_{4} \mathrm{~V}_{1.9} \mathrm{Mo}_{0.1} \mathrm{O}_{11.05}(x$ $=0.1)$

\subsubsection{Mechanism of propene oxidation on $\gamma-\mathrm{Bi}_{2} \mathrm{MoO}_{6}$}

The kinetics of propene oxidation over $\gamma-\mathrm{Bi}_{2} \mathrm{MoO}_{6}$, which has an aurivillius structure, and $\alpha-\mathrm{Bi}_{2} \mathrm{Mo}_{3} \mathrm{O}_{12}$, which has a scheelite structure, are identical. For both catalysts, the rate is first order in the partial pressure of propene and zero order in the partial pressure of oxygen. Isotopic tracer studies for both catalysts show that the reaction proceeds by a Mars van Krevelen mechanism involving oxygen atoms of the lattice [30]. Moreover, the reaction kinetics suggests that the rate-limiting step involves cleavage of a $\mathrm{C}-\mathrm{H}$ bond in the methyl group of propene [31]. There are also further similarities in the catalytic properties of $\gamma-\mathrm{Bi}_{2} \mathrm{MoO}_{6}$ and $\alpha-\mathrm{Bi}_{2} \mathrm{Mo}_{3} \mathrm{O}_{12}$. As noted in Table 3 both catalysts exhibit virtually the same activity per unit area and both have very similar activation energies $18.8 \mathrm{kcal} / \mathrm{mol}$ for $\gamma-\mathrm{Bi}_{2} \mathrm{MoO}_{6}$ and $19.9 \mathrm{kcal} / \mathrm{mol}$ for $\alpha-\mathrm{Bi}_{2} \mathrm{Mo}_{3} \mathrm{O}_{12}$.

The first question then is the whether the type of oxygen atoms involved in the oxidation of propene over $\alpha-\mathrm{Bi}_{2} \mathrm{Mo}_{3} \mathrm{O}_{12}$ and $\gamma-\mathrm{Bi}_{2} \mathrm{MoO}_{6}$ is the same? In situ XANES studies conducted on $\alpha-\mathrm{Bi}_{2} \mathrm{Mo}_{3} \mathrm{O}_{12}$ indicate that $\mathrm{Bi}$ remains in the $3+$ state and does not undergo reduction, whereas Mo undergoes reduction from the $6+$ to the $5+$ oxidation state and then is rexodized in the course of propene oxidation [17]. This conclusion is supported by DFT studies, which reveal further that the most reactive $\mathrm{O}$ atoms are those in $\mathrm{Mo}=\mathrm{O}$ bonds that interact with the lone pair of proximal $\mathrm{Bi}$ atoms (e.g., equatorial $\mathrm{Mo}=\mathrm{O}$ bonds) $[15,16]$. This interaction destabilizes the HOMO and stabilizes the LUMO 
of the molybdate species, thereby facilitating the transfer of an electron into a Mo-O p* orbital.

By contrast to $\alpha-\mathrm{Bi}_{2} \mathrm{Mo}_{3} \mathrm{O}_{12}, \gamma-\mathrm{Bi}_{2} \mathrm{MoO}_{6}$ has a layered structure, as shown in Figure 6. Three different type of oxygen can be distinguished. The first, O1 is only coordinated to bismuth and is located in the $\left(\mathrm{Bi}_{2} \mathrm{O}_{2}\right)^{2+}$ layer. The second type of oxygen, $\mathrm{O} 2$ is in the $\left(\mathrm{MoO}_{2}\right)^{2-}$ layer and is only coordinated to molybdenum. The third type of oxygen, $\mathrm{O} 3$ is located at the top and bottom of the octahedron around the molybdenum and is coordinated to both bismuth and molybdenum [32].

Several attempts to identify the active form of oxygen in $\gamma-\mathrm{Bi}_{2} \mathrm{MoO}_{6}$ have been reported. Otsubo et al. [33] and Miura et al. [34] prepared $\gamma-\mathrm{Bi}_{2} \mathrm{MoO}_{6}$ by solid state reaction of $\mathrm{Bi}_{2}{ }^{18} \mathrm{O}_{3} \bullet \mathrm{MoO}_{3}$ and $\mathrm{Bi}_{2} \mathrm{O}_{3} \bullet \mathrm{Mo}^{18} \mathrm{O}_{3}$. While their results suggest that the formation of acrolein formation involves the $\mathrm{O} 1$ atoms of the $\left(\mathrm{Bi}_{2} \mathrm{O}_{2}\right)^{2+}$ layers rather than the oxygen atoms of the $\left(\mathrm{MoO}_{2}\right)^{2-}$ layers, this conclusion is not definitive because at the high temperature required for the synthesis of $\gamma-\mathrm{Bi}_{2} \mathrm{MoO}_{6}$, oxygen migration occurs readily leading to complete scrambling of all oxygen atoms $[35,36]$. The likelihood that O1 is not the active form of oxygen is supported by the theoretical work of Dadyburjor et al. [37], who calculated the activation energies for removal of oxygen from $\gamma-\mathrm{Bi}_{2} \mathrm{MoO}_{6}$. This work revealed that the activation energies for removal of $\mathrm{O} 1, \mathrm{O} 2$, and $\mathrm{O} 3$ are $80 \mathrm{eV}$, $2 \mathrm{eV}$, and $3 \mathrm{eV}$, respectively. These results suggest that $\mathrm{O} 2$ and $\mathrm{O} 3$ are much more likely to be the active form of O. XPS studies by Ono et al. [38] show that the Mo/Bi ratio at the surface of $\gamma-\mathrm{Bi}_{2} \mathrm{MoO}_{6}$ is 0.8 , suggesting that $\mathrm{O} 2$ and $\mathrm{O} 3$ oxygen atoms should be present at the catalyst surface. The strong similarity of the activation energies for propene oxidation over $\alpha-\mathrm{Bi}_{2} \mathrm{Mo}_{3} \mathrm{O}_{12}$ and $\gamma-\mathrm{Bi}_{2} \mathrm{MoO}_{6}$, also suggests that the oxygen atom involved in the rate-limiting step is similar in both cases. As noted above, in the case of $\alpha$ - 
$\mathrm{Bi}_{2} \mathrm{Mo}_{3} \mathrm{O}_{12}$ this is the equatorial oxygen, which interacts with the lone pair of $\mathrm{Bi}$ in a structure that that can be described as $\mathrm{Bi}{ }^{\cdots} \mathrm{O}=\mathrm{Mo}$, in which the $\mathrm{Bi}-\mathrm{O}$ distance is $2.7 \AA$. Figure 6 shows that $\mathrm{O} 2$ is located $2.5 \AA$ from $\mathrm{Bi}$ so it is reasonable to expect that $\mathrm{O} 2$ interacts with $\mathrm{Bi}$ in a manner similar to that of the equatorial oxygen atom in $\alpha$ $\mathrm{Bi}_{2} \mathrm{Mo}_{3} \mathrm{O}_{12}$. Thus, we propose that the similarities in the activity of $\gamma-\mathrm{Bi}_{2} \mathrm{MoO}_{6}$ and $\alpha$ $\mathrm{Bi}_{2} \mathrm{Mo}_{3} \mathrm{O}_{12}$ are a consequence of the similarity in the active form of oxygen in both catalysts $-\mathrm{O} 2$ in the case of $\gamma-\mathrm{Bi}_{2} \mathrm{MoO}_{6}$ and equatorial $\mathrm{O}$ in the case of $\alpha-\mathrm{Bi}_{2} \mathrm{Mo}_{3} \mathrm{O}_{12}$.

The kinetics of propene oxidation to acrolein are identical for $\gamma-\mathrm{Bi}_{2} \mathrm{MoO}_{6}$ and $\alpha$ $\mathrm{Bi}_{2} \mathrm{Mo}_{3} \mathrm{O}_{12}$. The observed form of the rate expression can be rationalized on the basis of the reaction mechanism shown in Scheme 1 for $\alpha-\mathrm{Bi}_{2} \mathrm{Mo}_{3} \mathrm{O}_{12}$ [17]. As discussed previously, when the catalyst is fully oxidized and propene is weakly adsorbed on the catalyst surface, the rate of propene oxidation to acrolein is given by:

$$
\text { rate }=K_{1} k_{2} P_{C_{3} H_{6}}[S]=k_{\text {app }} P_{C_{3} H_{6}}
$$

Here $k_{i}$ is the rate coefficient of reaction $i, K_{i}$ is the equilibrium constant for reaction $i$, and $[\mathrm{S}]$ is the number of activate site per unit BET surface area of the catalyst. In our view, the mechanism shown in Scheme 1 should also apply to propene oxidation over $\gamma$ $\mathrm{Bi}_{2} \mathrm{MoO}_{6}$.

\subsubsection{Mechanism of propene oxidation on $\mathrm{Bi}_{4} \mathrm{~V}_{2} \mathrm{O}_{11}$ and on $\mathrm{Bi}_{4} V_{1.9} \mathrm{Mo}_{0.1} \mathrm{O}_{11.05}(x=0.1)$}

While there are similarities in the catalytic properties of $\mathrm{Bi}_{4} \mathrm{~V}_{2} \mathrm{O}_{11}$, which has an aurivillius structure, and $\mathrm{BiVO}_{4}$, which has a scheelite structure, there are also notable differences. The similarity is in the reaction kinetics, which for both catalysts are first order in the partial pressure of propene and zero order in the partial pressure of oxygen. The apparent activation energies are also nearly identical of the two catalysts -14.5 $\mathrm{kcal} / \mathrm{mol}$ for $\mathrm{BiVO}_{4}$ and $14.4 \mathrm{kcal} / \mathrm{mol}$ for $\mathrm{Bi}_{4} \mathrm{~V}_{2} \mathrm{O}_{11}$. What is different, though, are the 
catalyst activity and selectivity. As can be seen in Table 3, the activity of $\mathrm{BiVO}_{4}$ for propene oxidation to acrolein is more than 40 times larger than that for $\mathrm{Bi}_{4} \mathrm{~V}_{2} \mathrm{O}_{11}$ under identical reaction conditions. Table 2 also shows that the intrinsic selectivity to acrolein is significantly higher for $\mathrm{BiVO}_{4}(76 \%)$ than that for $\mathrm{Bi}_{4} \mathrm{~V}_{2} \mathrm{O}_{11}(39 \%)$. It is notable, though, that both catalysts show a monotonic decrease in the acrolein selectivity and corresponding rise in the selectivity to $\mathrm{CO}_{2}$ with increasing propene conversion, whereas the selectivities to $\mathrm{CO}, \mathrm{CH}_{3} \mathrm{COOH}$, and $\mathrm{CH}_{3} \mathrm{CHO}$ remain constant with propene conversion. These trends indicate that acrolein readily undergoes combustion to $\mathrm{CO}_{2}$ over both $\mathrm{BiVO}_{4}$ and $\mathrm{Bi}_{4} \mathrm{~V}_{2} \mathrm{O}_{11}$ as the concentration of acrolein in contact with the catalyst increases. The differences in the activity and selectivity of $\mathrm{Bi}_{4} \mathrm{~V}_{2} \mathrm{O}_{11}$ and $\mathrm{BiVO}_{4}$ are attributed to differences in the activity of the oxygen atoms present at the surface of the two materials. As discussed below the $\mathrm{O}$ atoms present at the surface of $\mathrm{Bi}_{4} \mathrm{~V}_{2} \mathrm{O}_{11}$ are significantly more active than those at the surface of $\mathrm{BiVO}_{4}$. This difference can lead to higher rates of oxidation of the vinylalkoxide intermediate to acrolein (see Scheme 1) and consequently to a lower intrinsic selectivity to acrolein, as well as to a greater tendency for acrolein to combust as the acrolein concentration increases with increasing propene conversion. The points are discussed in more detail below.

For molybdenum-substituted $\mathrm{Bi}_{4} \mathrm{~V}_{2} \mathrm{O}_{11}, \mathrm{Bi}_{4} \mathrm{~V}_{1.9} \mathrm{Mo}_{0.1} \mathrm{O}_{11.05}(\mathrm{x}=0.1)$, the activity and intrinsic selectivity of acrolein formation are higher than that of $\mathrm{Bi}_{4} \mathrm{~V}_{2} \mathrm{O}_{11}$ (Table 2) but still lower than that of $\mathrm{BiVO}_{4}$. Figure 4 also shows that with increasing propene conversion, the selectivity to acrolein decreases and that to $\mathrm{CO}_{2}$ increases. Further discussion of these trends is given below.

\subsection{Band Gap Energy as a Descriptor of Activation Energy}


We have recently shown that the apparent activation energy for propene oxidation to acrolein correlates with the band gap of catalyst of varying composition but all having a scheelite structure. This relationship has been rationalized on the basis of a Born-Haber cycle and the recognition that the largest contributor to this cycle is the band gap energy, which is also the component most dependent on catalyst composition [22]. The question that we now ask is whether a similar correlation holds for catalysts having the aurivillius structure.

Figure 7 shows that the apparent activation energy for propene oxidation correlates linearly with the band gap for catalyst of different composition having either the scheelite or aurivillius structure. The only difference is that for the same band gap, the apparent activation energies are about $1.5 \mathrm{kcal} / \mathrm{mol}$ higher for catalysts with the aurivillius than the scheelite structure. Since the apparent activation energy is the sum of the enthalpy of propene adsorption and the intrinsic activation energy, we propose that the slightly higher activation energies observed for catalysts with the aurivillius structure compared to the scheelite structure is due the slightly lower heat of adsorption for propene on the former structure. Unfortunately, to the best of our knowledge, the difference in the heats of adsorption for the two types of structures has not been reported, and, therefore, we cannot verify this hypothesis.

The results presented in Figure 7 suggest that catalysts with low band gaps should be exhibit a higher activity for propene oxidation to acrolein per active site than those with higher band gaps. While this conclusion is true for catalysts with band gaps above about $\sim 2.1 \mathrm{eV}$, it does not hold for catalyst with lower band gaps. As shown in this study for $\mathrm{Bi}_{4} \mathrm{~V}_{2} \mathrm{O}_{11}$ and $\mathrm{Bi}_{4} \mathrm{~V}_{1.9} \mathrm{Mo}_{0.1} \mathrm{O}_{11.05}$, and reported earlier for $\mathrm{BiVO}_{4}$, catalysts with band gaps below $\sim 2.1 \mathrm{eV}$ show both lower intrinsic selectivities to acrolein and higher activity 
for acrolein combustion. This pattern is nicely illustrated in Figure 8. Two factors can account for the loss of acrolein selectivity for catalysts with band gaps $<2.1 \mathrm{eV}$. Scheme 2 shows a possible pathway for the oxidation of the vinylalkoxide formed as an intermediate leading to acrolein [17]. Loss of an $\mathrm{H}$ atom from this intermediate initiates a cascade of steps leading to $\mathrm{CO}$ and $\mathrm{CO}_{2}$. It is notable that the participation of an oxygen atom from $\mathrm{O}_{2}$ adsorbed from the gas phase accounts for the observed positive order in oxygen partial pressure of the rate of $\mathrm{CO}_{\mathrm{x}}$ formation. Clearly then, the more active the surface oxygen, the higher will be the rate of $\mathrm{CO}_{\mathrm{x}}$ formation paralleling the rate of acrolein formation. A high chemical activity of surface oxygen could also be responsible for the secondary combustion of acrolein.

\section{Conclusions}

The oxidation of propene to acrolein has been investigated over aurivilliusstructured mixed metal oxides, $\gamma-\mathrm{Bi}_{2} \mathrm{MoO}_{6}, \mathrm{Bi}_{4} \mathrm{~V}_{2} \mathrm{O}_{11}$, and Mo-substituted $\mathrm{Bi}_{4} \mathrm{~V}_{2} \mathrm{O}_{11}$, and the activity and selectivity of these materials are compared to those for similar catalysts prepared with the scheelite structure. All of the catalysts exhibit similar kinetics - the rate of acrolein formation is first order in the partial pressure of propene and zero order in the partial pressure of oxygen. These kinetics can be rationalized on the basis of the mechanism shown in Scheme 1. Both sets of catalysts show a linear correlation in the apparent activation energy with the band gap of the catalyst measured at the reaction conditions (see Figure 7). However, for the same band gap, the apparent activation energy for propene oxidation to acrolein is about $1.5 \mathrm{kcal} / \mathrm{mol}$ higher for catalysts having the aurivillius structure. This difference is attributed to the lower heat of propene adsorption on the aurivillius structure. The results of this study also reveal another 
interesting feature. As seen in Figure 8, catalysts with band gaps of above $\sim 2.1 \mathrm{eV}$ exhibit high intrinsic acrolein selectivities, $\sim 75 \%$, whereas catalysts with band gaps below $\sim 2.1 \mathrm{eV}$ exhibit significant lower intrinsic acrolein selectivities. It is also observed that the acrolein selectivity is independent of propene conversion for catalysts with band gaps above $\sim 2.1 \mathrm{eV}$, whereas catalysts with band gaps below $\sim 2.1 \mathrm{eV}$ exhibit a strong decrease in acrolein selectivity with increasing propene conversion as a consequence of acrolein combustion. These findings clearly indicate that there is no advantage to developing propene oxidation catalysts with band gaps below $\sim 2.1 \mathrm{eV}$.

\section{Acknowledgements}

This work was funded by Director, Office of Science, Office of Basic Energy Sciences of the U.S. Department of Energy under Contract No. DE-AC02-05CH11231.

\section{References}

[1] G.W. Keulks, L.D. Krenzke, T. M. Notermann, Adv. Catal. 27 (1978) 183-225.

[2] G. Ertl, H. Knozinger, F. Schuth, J. Weitkamp (Eds.) Handbook of Heterogeneous Catalysis, Wiley- VCH, Weinheim, 2008, pp. 3481.

[3] Y. Moro-Oka, W. Ueda, Adv. Catal. 40 (1994) 233-273.

[4] J.M.M. Millet, H. Ponceblanc, G. Coudurier, J.M. Herrmann, J.C. Vedrine, J. Catal. 142 (1993) 381-391.

[5] D. Carson, G. Coudurier, M. Forissier, J.C. Vedrine, J. Chem. Soc. Faraday Trans. I. 79 (1983) 1921-1929.

[6] H.H. Voge, C.D. Wagner, D.P. Setvenson, J. Catal. 2 (1963) 58-62.

[7] W.M.H. Sachtler. Rec. Trav. Chim. 82 (1963) 243-245.

[8] B. Grzybowska, J. Haber, J. Janas, J. Catal. 49 (1977) 150-163.

[9] W. Ueda, K. Asakawa, C.L. Chen, Y. Moro-Oka, T. Ikawa, J. Catal. 101 (1986) 360368.

[10] G.W. Keulks, J. Catal. 19 (1970) 232- 235.

[11] J. Haber, W. Turek, J. Catal. 190 (2000) 320-326.

[12] R.K. Grasselli, Top. Catal. 21 (2001) 79-88.

[13] R.K. Grasselli, J. Chem. Educ. 63 (1986) 216-221.

[14] L.C. Glaeser, J.F. Brazdil, M.A. Hazle, M. Mehicic, R.K. Grasselli, J. Chem. Soc., Faraday Trans. I 81 (1985) 2903-2912.

[15] A. Getsoian, V. Shapovalov, A. T. Bell, J. Phys. Chem. C 117 (2013) 7123-7137. 
[16] A. Getsoian, A. T. Bell, J. Phys. Chem. C 117(2013), 25562-25578.

[17] Z. Zhai, A. Getsoian, A. T. Bell, J. Catal. 308 (2013) 25-36.

[18] Y. Moro-Oka, W. Ueda, Adv. Catal. 40 (1994) 233-273.

[19] P.Porta, M.L. Jacono, M. Valigi, G. Minelli, A. Anichini, S.D. Rossi, D. Gazzoli. J.

Catal. 100(1986) 86-94

[20] S.D. Rossi, M.L. Jacono, P.Porta, M. Valigi, D. Gazzoli, G. Minelli, A. Anichini, J. Catal. 100(1986) 95-102

[21] D. Cordischi, M.L. Jacono, , D. Gazzoli, G. Minelli, P.Porta. J. Catal. 102(1986) 1-9

[22] A. Getsoian, Z. Zhai, A. T. Bell, J. Am. Chem. Soc. 136 (2014) 13684-13697.

[23] K. R. Kendall, C. Navas, J. K. Thomas, and H. Loye, "Recent Developments in

Oxide Ion Conductors : Aurivillius Phases," no. 15, pp. 642-649, 1996.

[24] G. Mairesse, P. Roussel, R. N. Vannier, M. Anne, G. Nowogrocki, Solid State Sci. 5 (2003) 861-869.

[25] R. N. Vannier, G. Mairesse, F. Abraham, J. Solid State Chem., 103 (1993) 441-446

[26] A. Phuruangrat, P. Jitrou, P. Dumrongrojthanath, N. Ekthammathat, B. Kuntalue, S.

Thongtem, T. Thongtem, J. Nanomater. 2013(2013) 1-8.

[27] A. M. Cruz and S. O. Alfaro, J. Mol. Catal. A Chem., 320 (2010) 85-91.

[28] S. J. Patwe, A. Patra, R. Dey, A. Roy, R. M. Kadam, S. N. Achary, and A. K. Tyagi, J. Am. Ceram. Soc., 96 (2013) 3448-3456.

[29] L.D. Krenzke, G.W. Keulks, J. Catal. 64 (1980) 295-302.

[30] L.D. Krenzke, G.W. Keulks, J. Catal. 61 (1980) 316-325.

[31] C.R. Adams, T.J. Jennings, J. Catal. 3 (1964) 549-558.

[32] R.G. Teller, J. F. Brazdel, R. K. Grasselli, Acta. Cryst., C40 (1984) 2001-2005.

[33] T.-T. Otsubo, H. Miura, Y. Morikawa, T. Shirasaki, J. Catal. 36 (1975) 240-243.

[34] H. Miura, T.-T. Otsubo, T. Shirasaki, Y. Morikawa, J. Catal.,56 (1979) 84-87.

[35] E.V. Hoefs, J.R. Monnier, G.W. Keulks. J. Catal. 57(1979) 331-337.

[36] L. T. Sim, C. K. Lee, A. R. West, J. Mater. Chem. 12 (2002) 17-19.

[37] D. B. Dadyburjor, E. Ruckenstein. J. Catal. 63 (1980) 383-388.

[38] T. Ono, K. Utsumi, S. Tsukamoto, H. Tamaru, M. Kataoka, F. Noguchi, J. Mol.

Catal. A Chem., 318 (2010) 94-100. 


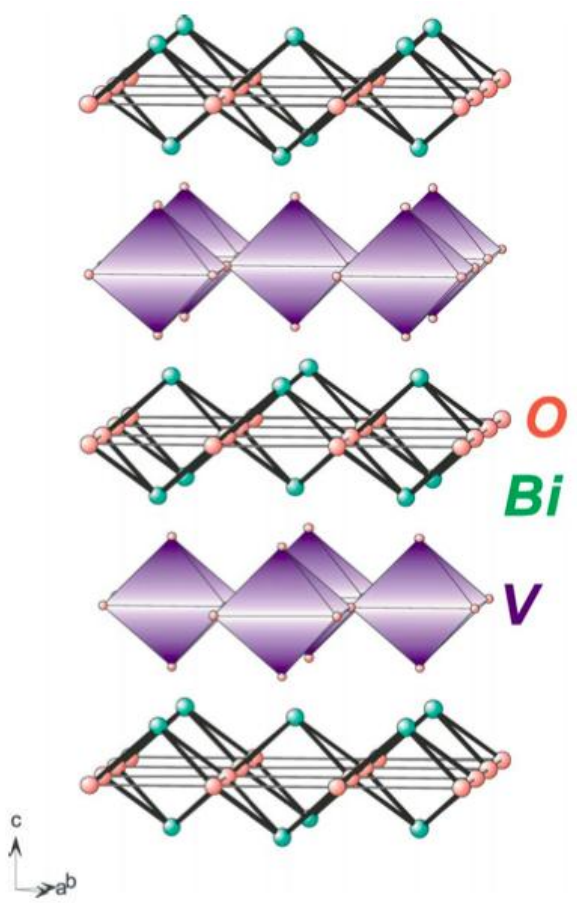

Figure 1. Ideal crystal structure of $\mathrm{Bi}_{4} \mathrm{~V}_{2} \mathrm{O}_{11}$ as a representative of aurivillius structure [24].

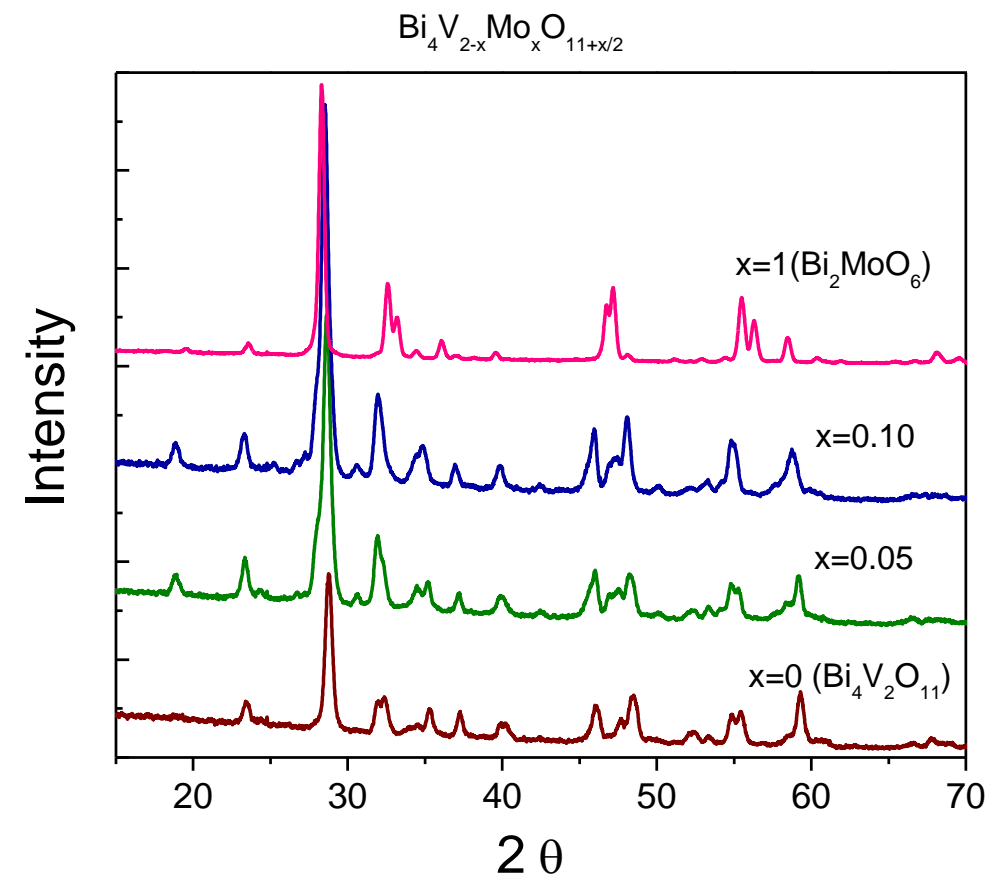

Figure 2. XRD patterns of $\mathrm{Bi}_{4} \mathrm{~V}_{2-\mathrm{x}} \mathrm{Mo}_{\mathrm{x}} \mathrm{O}_{11+\mathrm{x} / 2}$ catalysts. 


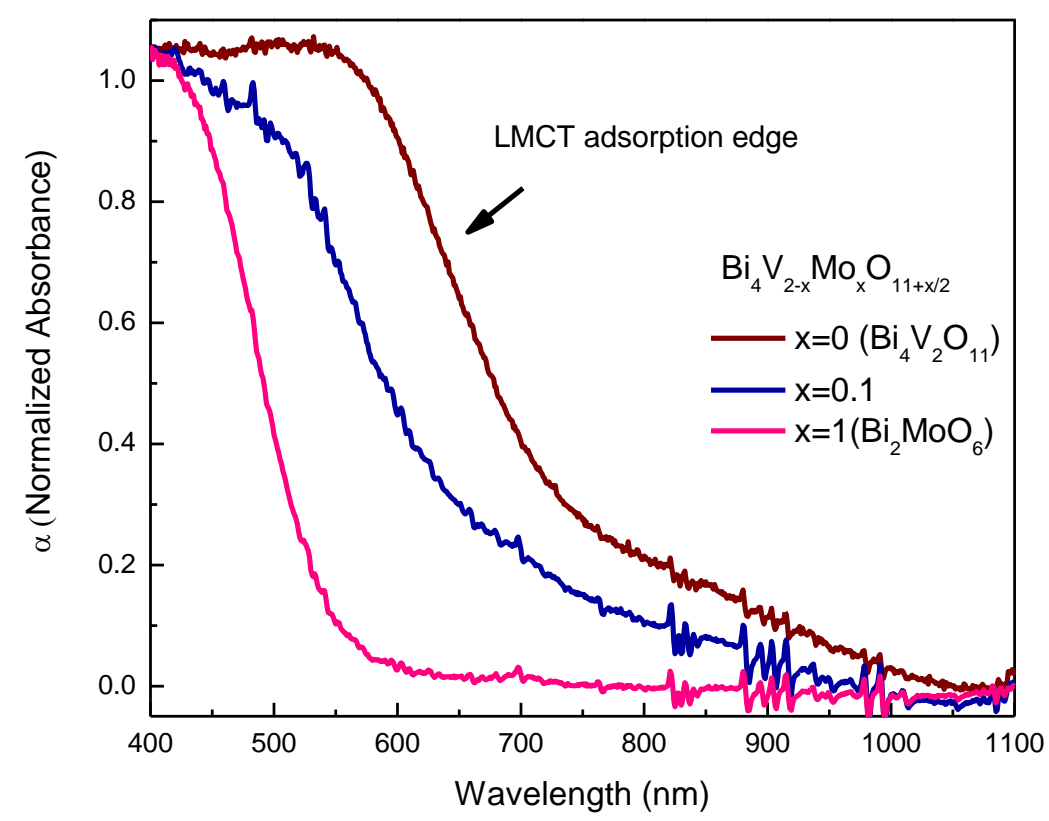

Figure 3: Diffuse reflectance UV-Visible absorption spectrum of $\mathrm{Bi}_{4} \mathrm{~V}_{2-\mathrm{x}} \mathrm{Mo}_{\mathrm{x}} \mathrm{O}_{11+\mathrm{x} / 2}$ measured at $673 \mathrm{~K}$. Labels mark the principal LMCT absorption edge.

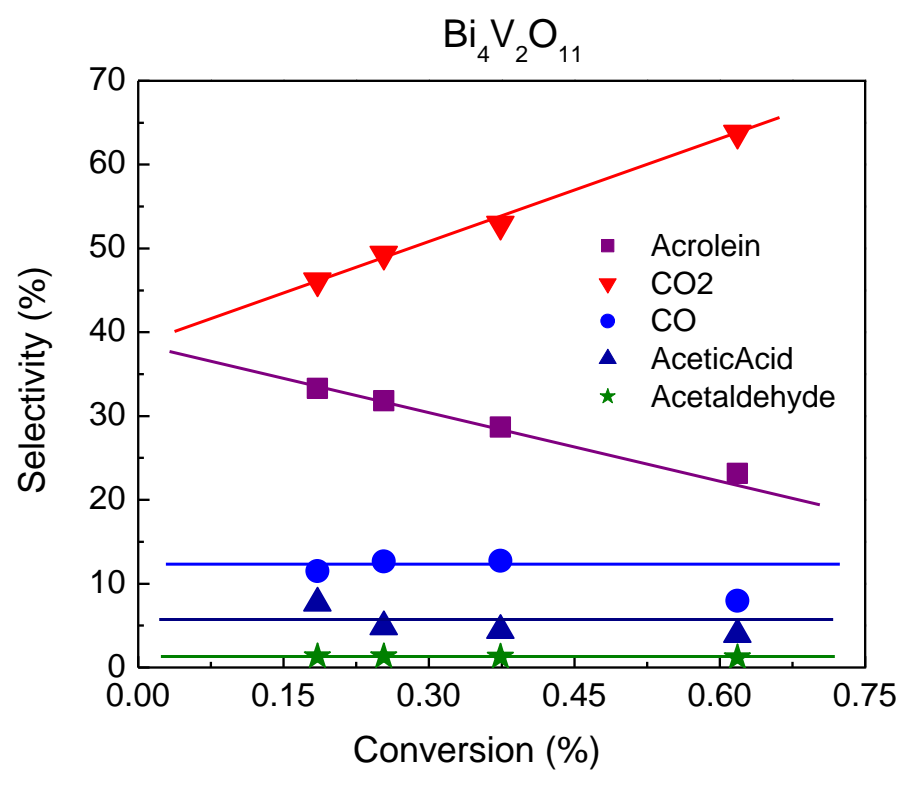



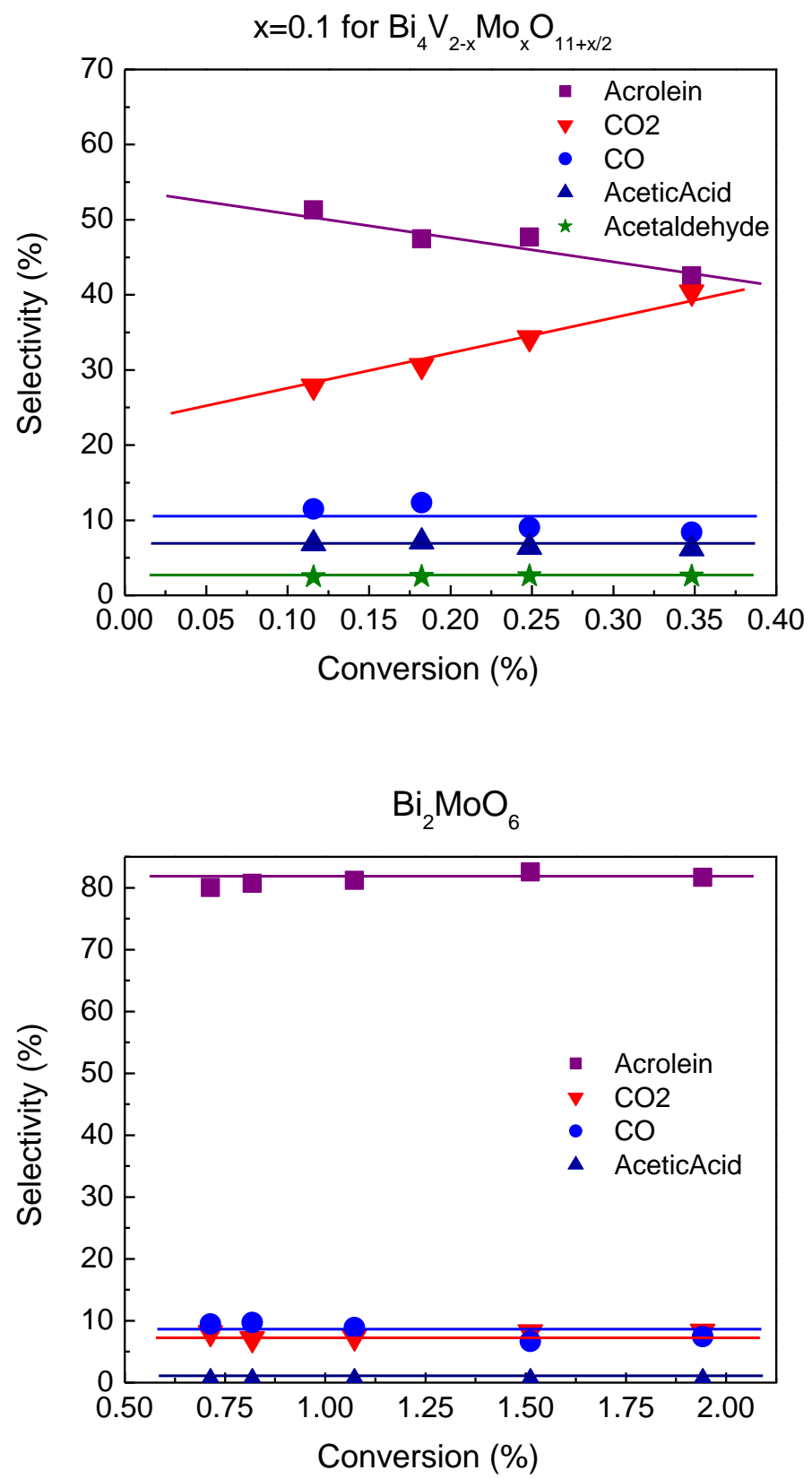

Figure 4. Variation in the selectivity of $\mathrm{Bi}_{4} \mathrm{~V}_{2-\mathrm{x}} \mathrm{Mo}_{\mathrm{x}} \mathrm{O}_{11+\mathrm{x} / 2}$ for propene oxidation to acrolein at $673 \mathrm{~K}$ and $\mathrm{P}_{\mathrm{C} 3 \mathrm{H} 6}=\mathrm{P}_{\mathrm{O} 2}=0.167$ atm measured as a function of propene conversion. 


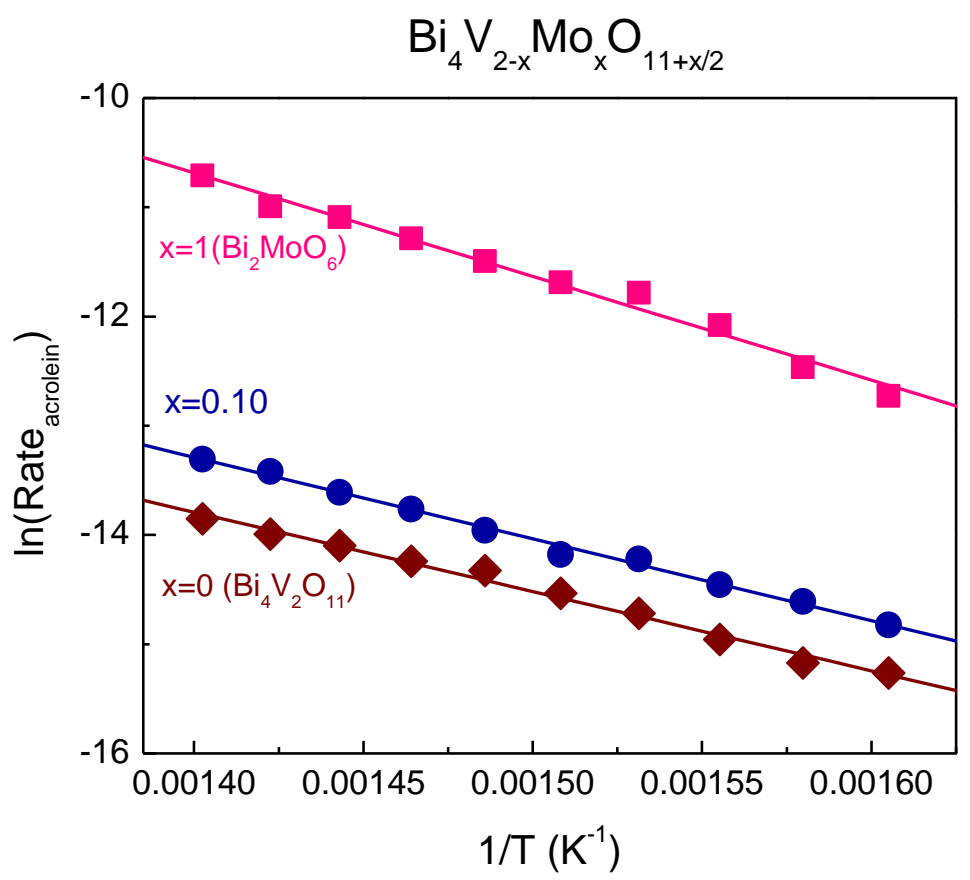

Figure 5. Arrhenius plots for propene oxidation to acrolein over $\mathrm{Bi}_{4} \mathrm{~V}_{2-\mathrm{x}} \mathrm{Mo}_{\mathrm{x}} \mathrm{O}_{11+\mathrm{x} / 2}$ catalysts. Reaction conditions: $\mathrm{T}=623 \mathrm{~K}-713 \mathrm{~K}$ and $\mathrm{P}_{\mathrm{C} 3 \mathrm{H} 6}=\mathrm{P}_{\mathrm{O} 2}=0.167 \mathrm{~atm}$. 


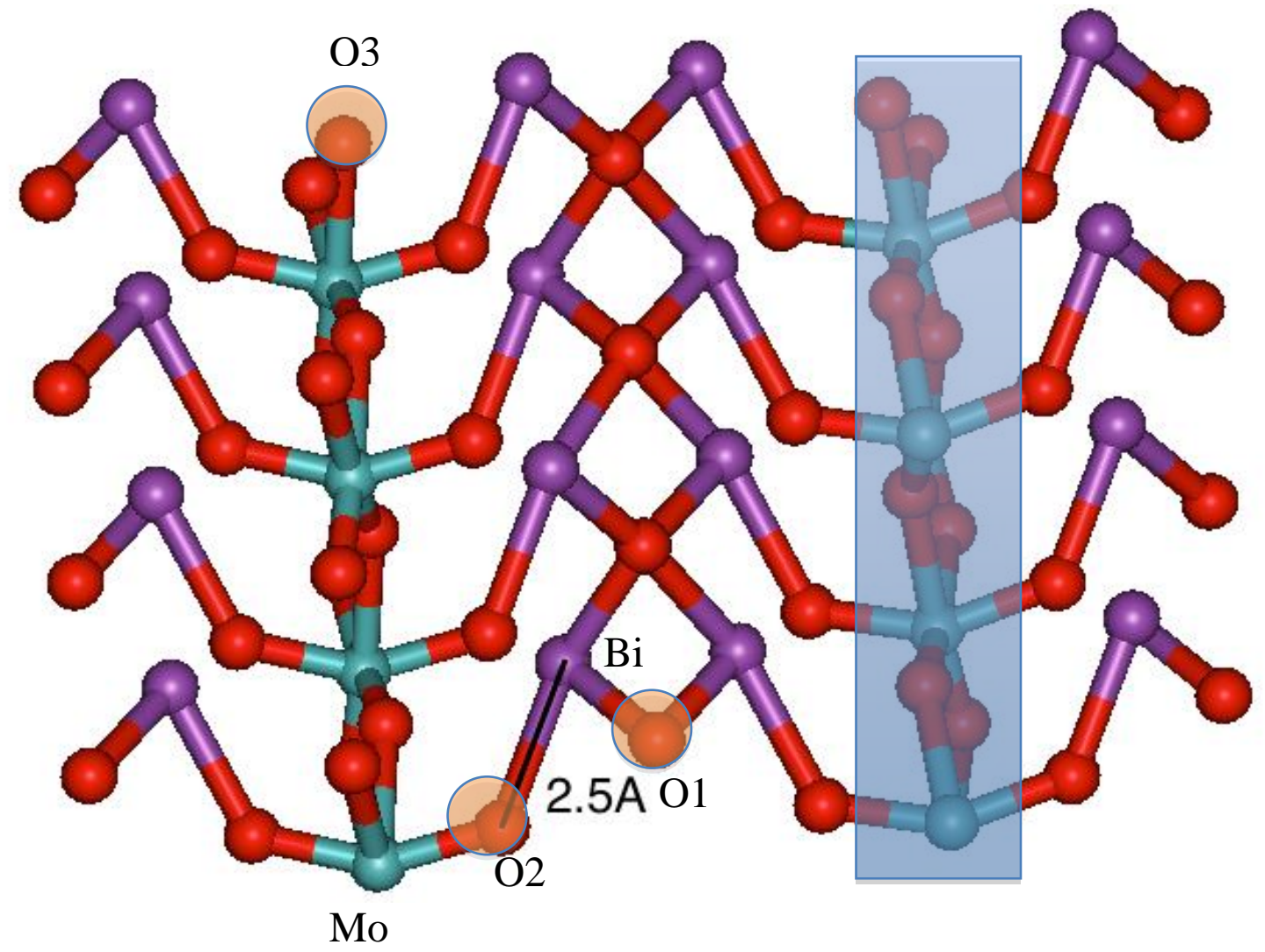

Figure 6. $\gamma-\mathrm{Bi}_{2} \mathrm{MoO}_{6}$ structure. Red: oxygen; Purple: bismuth; Green: molybdenum. O1, $\mathrm{O} 2$ and $\mathrm{O} 3$ refers to three different types of oxygen. 


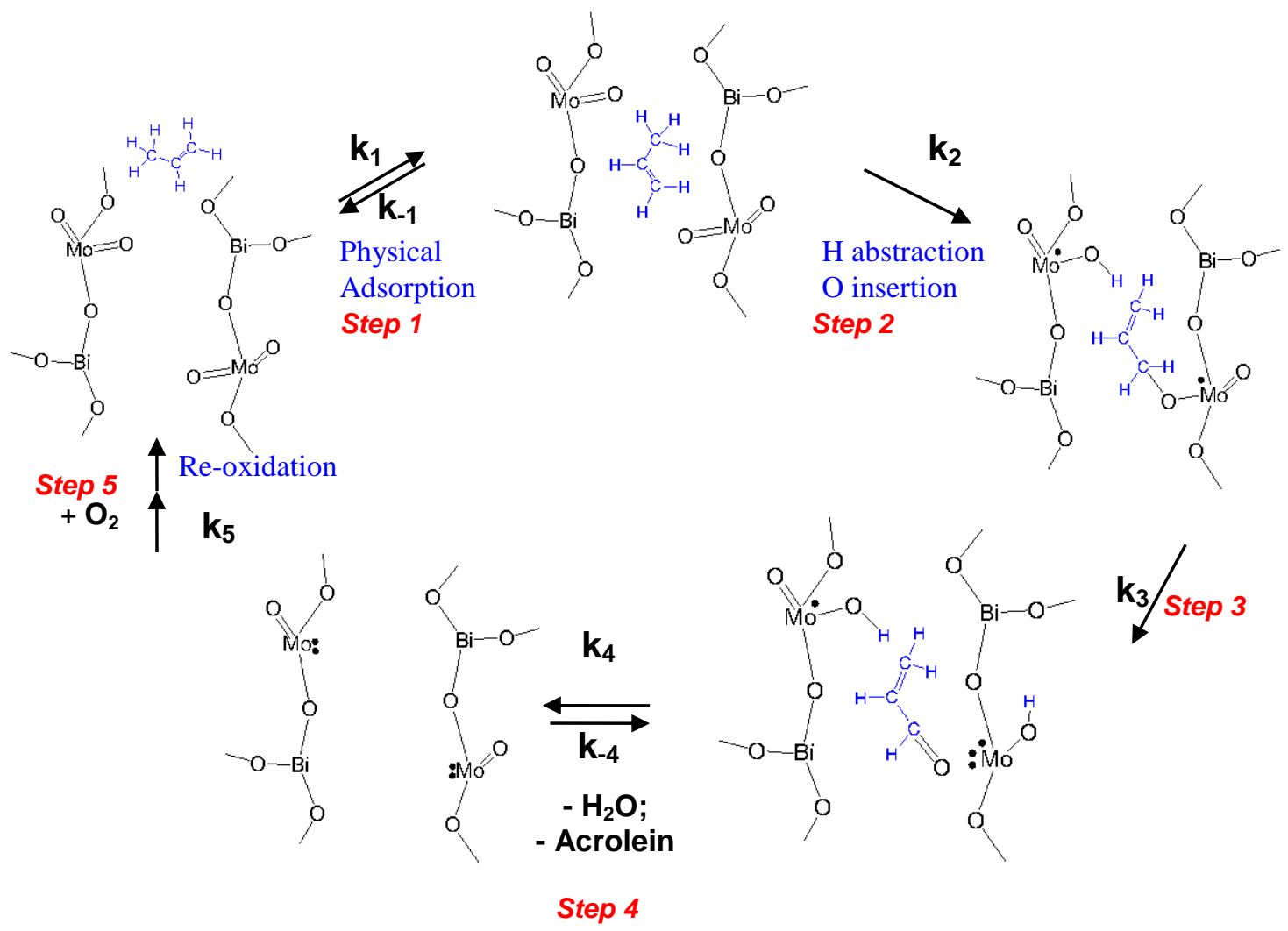

Scheme 1. The mechanism for the oxidation of propene to acrolein over $\mathrm{Bi}_{2} \mathrm{Mo}_{3} \mathrm{O}_{12}$ proposed on the basis of data reported in this study [17]. 


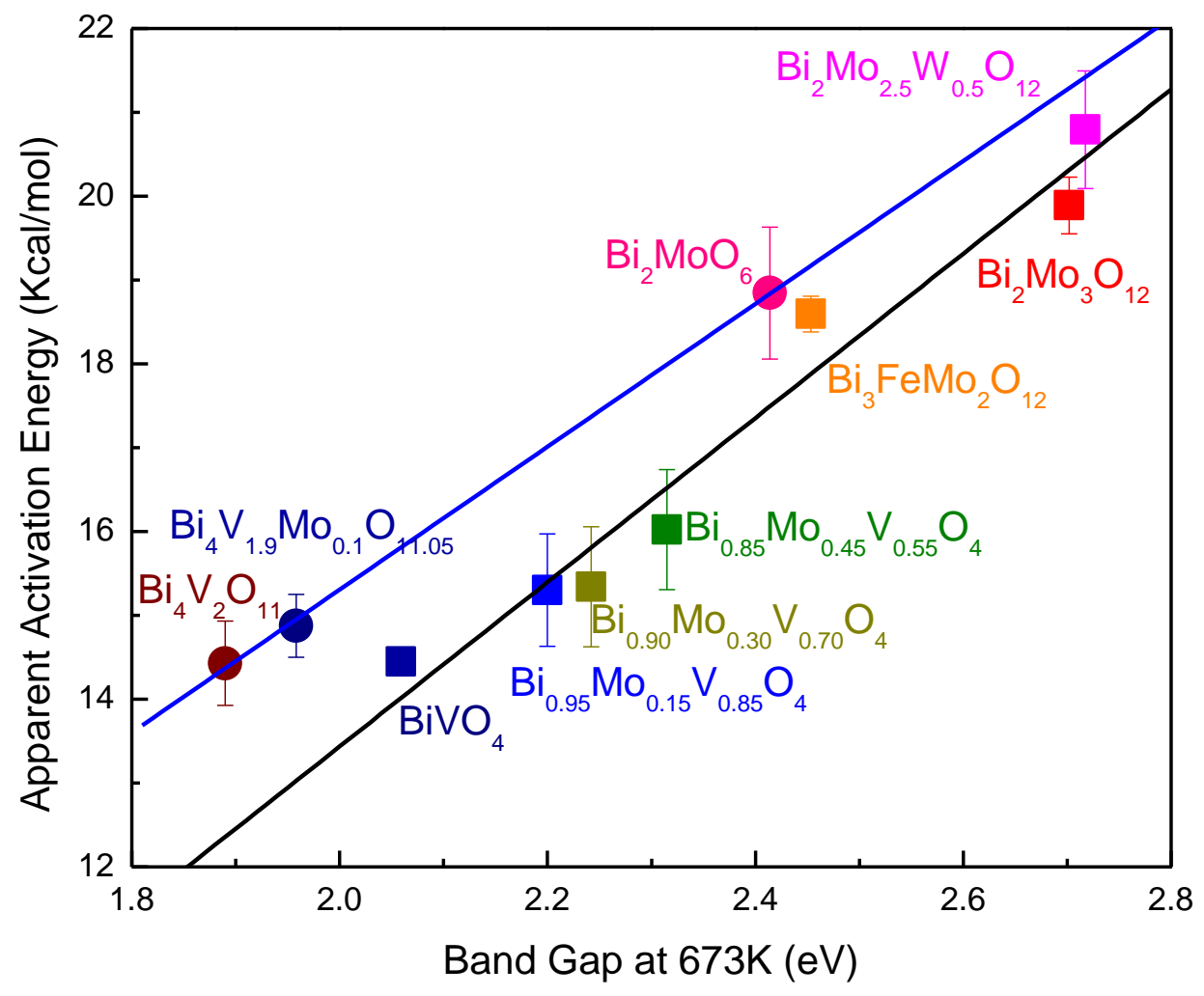

Figure 7: Apparent activation energies for oxidation of propene to acrolein versus the band gap measured at $673 \mathrm{~K}$ for catalysts having the scheelite (lower line, square) and aurivillius (upper line, circle) structures. Reaction conditions: $\mathrm{T}=673 \mathrm{~K}$ and $\mathrm{P}_{\mathrm{C} 3 \mathrm{H} 6}=\mathrm{P}_{\mathrm{O} 2}=$ $0.167 \mathrm{~atm}$. 


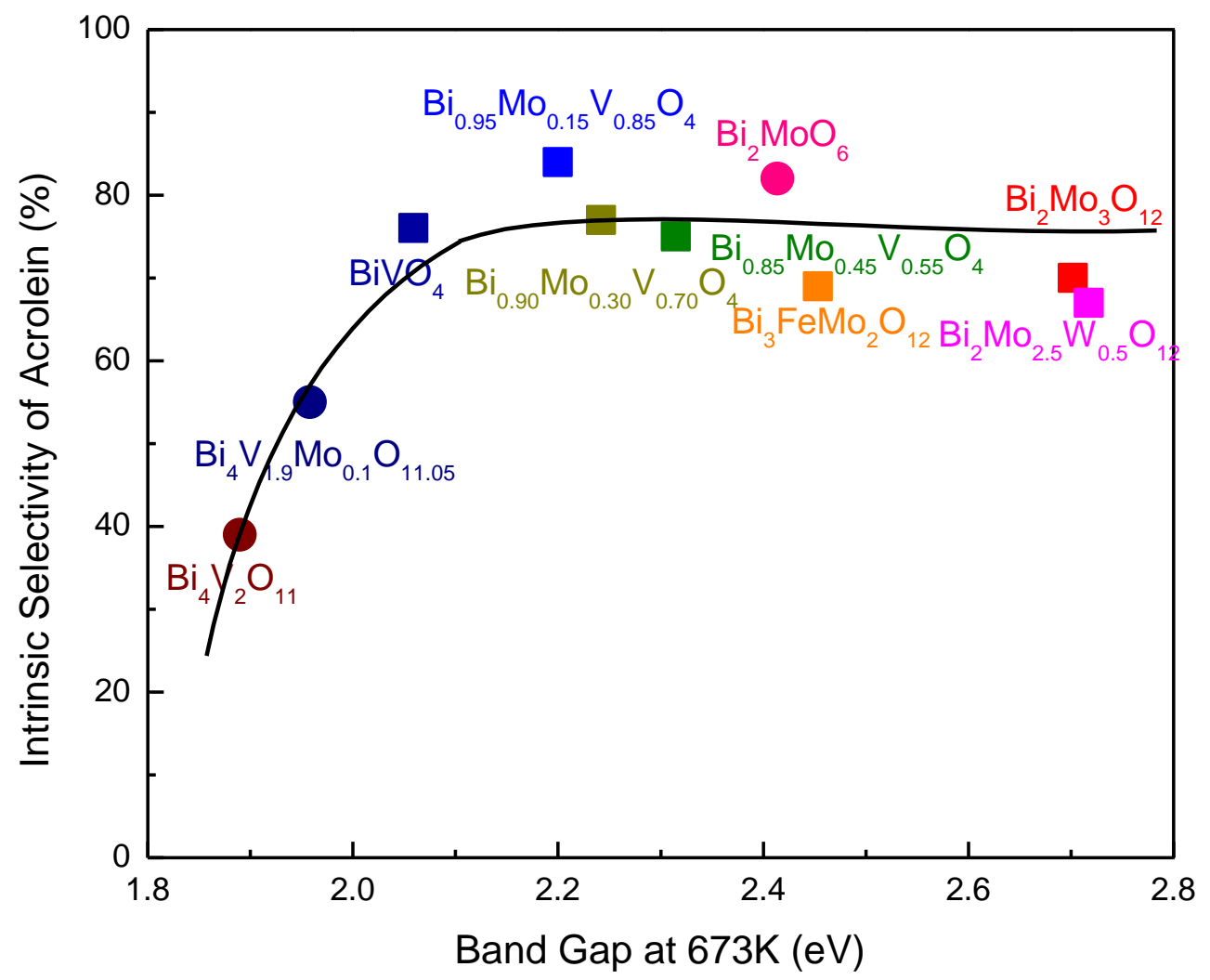

Figure 8: Intrinsic selectivity to acrolein versus the band gap measure at $673 \mathrm{~K}$ (scheelite, square; aurivillius, circle). Reaction conditions: $\mathrm{T}=673 \mathrm{~K}$ and $\mathrm{P}_{\mathrm{C} 3 \mathrm{H} 6}=\mathrm{P}_{\mathrm{O} 2}=0.167 \mathrm{~atm}$. 
Table 1. Kinetics and physical properties of $\mathrm{Bi}_{4} \mathrm{~V}_{2-\mathrm{x}} \mathrm{Mo}_{\mathrm{x}} \mathrm{O}_{11+\mathrm{x} / 2}$.

Note: Band-gap energies $(\mathrm{eV})$ were measured at $673 \mathrm{~K}$. Reaction orders in propene and oxygen were measured at $673 \mathrm{~K}$ for propene oxidation to acrolein. The partial pressures of propene or oxygen were fixed at 0.067 or 0.167 atm, respectively, while the other one was varied. Apparent activation energies $E_{\text {app }}$ for propene oxidation to acrolein were measured in the temperarure ranges of $623-713 \mathrm{~K} . \mathrm{P}_{\mathrm{C} 3 \mathrm{H} 6}=\mathrm{P}_{\mathrm{O} 2}=0.167 \mathrm{~atm}$.

\begin{tabular}{|l|c|c|c|c|}
\hline \multicolumn{1}{|c|}{ Catalyst } & $\begin{array}{c}\text { Band-Gap } \\
(673 \mathrm{~K})\end{array}$ & \multicolumn{2}{|c|}{ Reaction Order } & $\mathrm{E}_{\mathrm{G} p}$ \\
\cline { 3 - 4 } & & Propene (m) & Oxygen (n) & \multirow{2}{*}{$(\mathrm{kcal} / \mathrm{mol})$} \\
\hline $\mathrm{Bi}_{4} \mathrm{~V}_{2} \mathrm{O}_{11}$ & 1.89 & $1.0 \pm 0.1$ & $0.1 \pm 0.1$ & 14.4 \\
\hline $\mathrm{Bi}_{4} \mathrm{~V}_{1.9} \mathrm{Mo}_{0.1} \mathrm{O}_{11.05}$ & 1.96 & $1.0 \pm 0.0$ & $0.0 \pm 0.0$ & 14.9 \\
\hline $\mathrm{Bi}_{2} \mathrm{MoO}_{6}$ & 2.41 & $1.0 \pm 0.0$ & $0.1 \pm 0.1$ & 18.8 \\
\hline
\end{tabular}

Table 2. Reaction rate of propene consumption and intrinsic selectivity on $\mathrm{Bi}_{4} \mathrm{~V}_{2-}$ ${ }_{\mathrm{x}} \mathrm{Mo}_{\mathrm{x}} \mathrm{O}_{11+\mathrm{x} / 2}$ for the oxidation of propene at $673 \mathrm{~K}$ and $\mathrm{P}_{\mathrm{C} 3 \mathrm{H} 6}=\mathrm{P}_{\mathrm{O} 2}=0.167 \mathrm{~atm}$.

\begin{tabular}{|l|c|l|l|l|l|l|}
\hline \multicolumn{1}{|c|}{ Catalyst } & $\begin{array}{c}\text { Reaction rate of } \\
\text { propene } \\
\text { consumption } \\
\left(* 10^{-6} \text { mol/min }\right. \\
\left.\mathrm{m}^{2} / \mathrm{cat}\right)\end{array}$ & \multicolumn{5}{|c|}{ Selectivity (\%) } \\
\cline { 3 - 7 } & 1.6 & Acrolein & $\mathrm{CO}$ & $\mathrm{CO}_{2}$ & $\begin{array}{c}\text { Acetic } \\
\text { Acid }\end{array}$ & $\begin{array}{c}\text { Acetalde- } \\
\text { hyde }\end{array}$ \\
& 1.9 & 39 & 15 & 40 & 5 & 1 \\
\hline $\mathrm{Bi}_{4} \mathrm{~V}_{2} \mathrm{O}_{11}$ & 12.4 & 85 & 12.5 & 23 & 7 & 2.5 \\
\hline $\mathrm{Bi}_{4} \mathrm{~V}_{1.9} \mathrm{Mo}_{0.1} \mathrm{O}_{11.05}$ & 82 & 7.5 & 8 & 0 & 2.5 \\
\hline $\mathrm{Bi}_{2} \mathrm{MoO}_{6}$ & & & & &
\end{tabular}

Table 3. Apparent rate constant $\mathrm{k}_{\text {app }}$ for acrolein production on scheelite catalysts $\left(\mathrm{BiVO}_{4}\right.$ and $\left.\mathrm{Bi}_{2} \mathrm{Mo}_{3} \mathrm{O}_{12}\right)$ and aurivilius catalysts $\left(\mathrm{Bi}_{4} \mathrm{~V}_{2} \mathrm{O}_{11}\right.$ and $\left.\mathrm{Bi}_{2} \mathrm{MoO}_{6}\right) . \mathrm{P}_{\mathrm{C} 3 \mathrm{H} 6}=\mathrm{P}_{\mathrm{O} 2}=0.167$ atm, $673 \mathrm{~K}$.

\begin{tabular}{|l|c|c|c|}
\hline \multicolumn{1}{|c|}{ Catalyst } & \multicolumn{1}{c|}{$\mathrm{k}_{\text {app }}$} & Catalyst & $\mathrm{k}_{\text {app }}$ \\
& $\left(* 10^{-5} \mathrm{~mol} / \mathrm{min} \mathrm{m} /\right.$ cat atm $)$ & & $\left(* 10^{-5} \mathrm{~mol} / \mathrm{min} \mathrm{m}^{2} / \mathrm{cat} \mathrm{atm}\right)$ \\
\hline $\mathrm{BiVO}_{4}$ & 17.4 & $\mathrm{Bi}_{4} \mathrm{~V}_{2} \mathrm{O}_{11}$ & 0.4 \\
\hline $\mathrm{Bi}_{2} \mathrm{Mo}_{3} \mathrm{O}_{12}$ & 6.7 & $\mathrm{Bi}_{2} \mathrm{MoO}_{6}$ & 6.4 \\
\hline
\end{tabular}



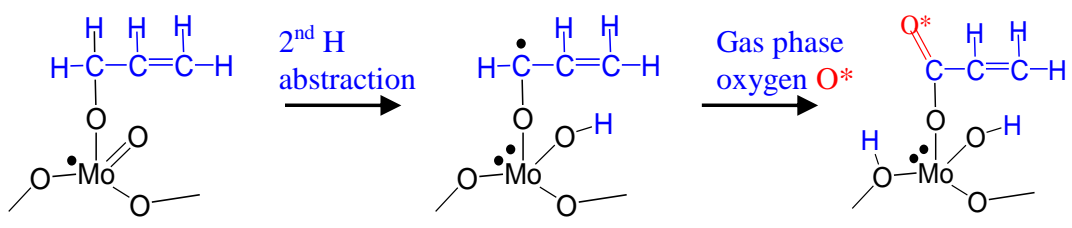

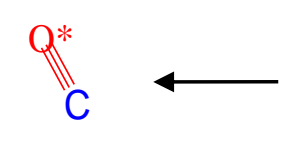

co production
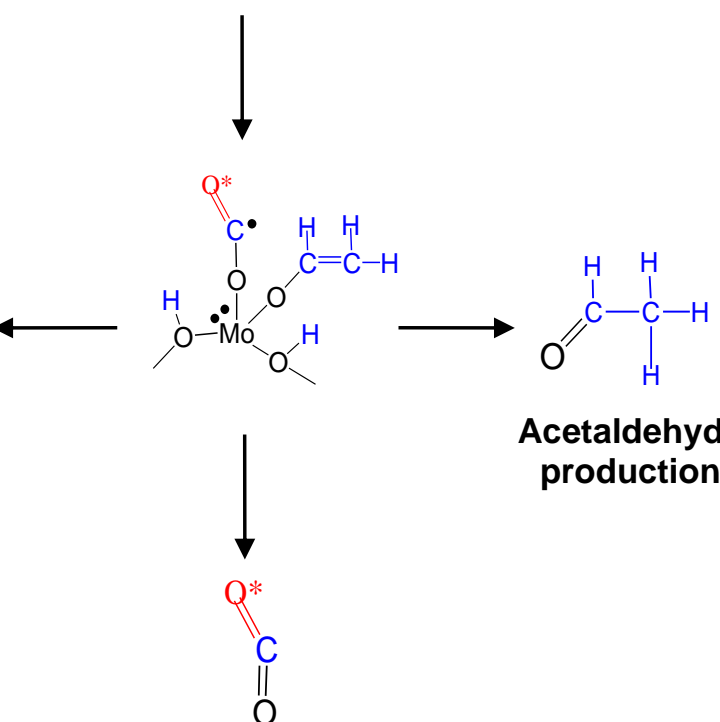

$\mathrm{CO}_{2}$ production
Acetaldehyde production

Scheme 2. Possible pathway for $\mathrm{CO}$ and $\mathrm{CO}_{2}$ formation on $\mathrm{Bi}_{2} \mathrm{MoO}_{6}$ during the oxidation of propene [17]. 


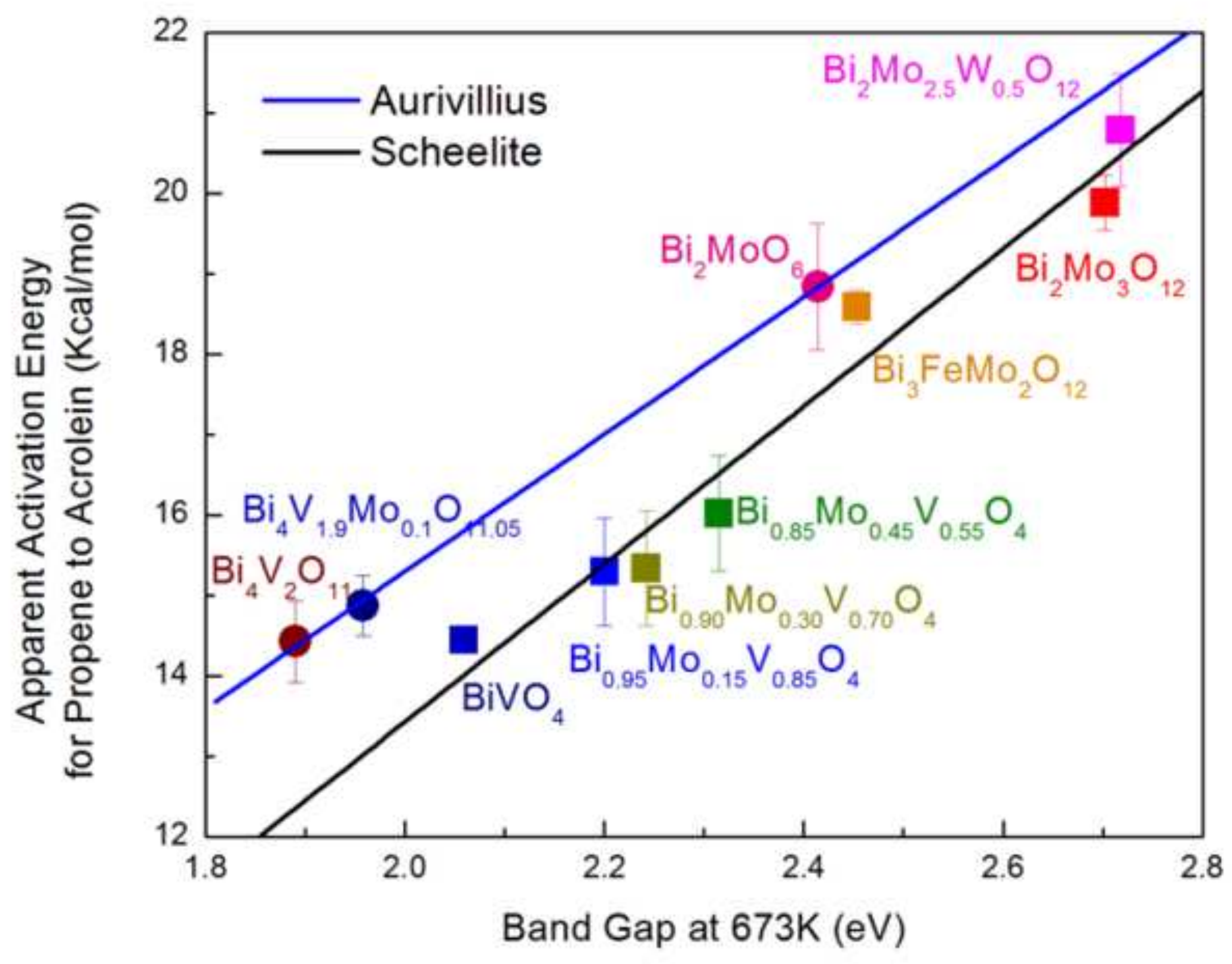

